\title{
ПРО ДЕЯКІ ОСОБЛИВОСТІ СОНЕТНОГО ВІРША IBAНА ФРАНКА
}

Стаття присвячена сонетній творчості I. Франка, зокрема ролі поета в оновленні традиціі сонетного вірша. На власне мовному рівні в поетииі Франкових текстів означено ряд явищ, традиційно застережених шьодо сонетного вірша, ие насамперед повтори тих самих слів, іноді иілих рядків у риторичних та риторично-запитальних реченнях, незавершеність фрази з перенесенням у наступний рядок (анжамбеман) тощо. Розглянуто деякі структурно-композииійні особливості сонетних творів автора. І. Франко, культивуючи сонетний віри як поет, водночас немало зробив для дослідження його як теоретик, літературознавець, перекладач (сонети Данте, Шекспіра). Сонетна творчість Івана Франка є не лише вериинною віхою здобутків украӥнського сонету наприкінці ХІХ-го століття, а й своєрідним підмурівком для подальших новітніх пошуків у цььому жанрі.

Ключові слова: Іван Франко, сонет, текст, поетика, словесний повтор, анжамбеман, структурно-композиційна організація.

Moisiienko A. On Some Peculiarities of Ivan Franko's Sonnets. The article is devoted to Ivan Franko's sonnets, in particular to the role of the poet in the renewal of the sonnetic tradition. The author who played a leading role in the establishment of sonnet forms in Ukrainian classic literature contributed a lot to the semantic and formal renewal of the sonnet; the very titles of his poems ('Science', 'Kotliarevskyi', The Song of the Future', 'Prison Sonnets' cycle) show that the poet was not satisfied with the generally accepted opinion about the limitations of the sonnet genre, usually characterized by general lyrics and intimate theme. At the linguistic level particularly, Ivan Franko's texts contain a number of phenomena, traditionally not allowed to be used in a sonnet. These are mostly repetitions of the same words (sometimes of the whole lines), unfinished phrases with a break to the next line (enjambment), rhymed endings e.g. мені ти - боліти, which were very rare phenomena at that time. The article also studies some structural and compositional peculiarities of Ivan Franko's sonnets. The poetics of the repeating word in rhetorical and rhetorical-interrogative sentences dominates in many of his sonnets. In some sonnets the rhetorical-interrogative construction of the first line acquires an affirmative intonation in the second stanza (the sonnet "Sistine Madonna"). In others, on the contrary, we observe the reverse figurative movement from the actual assertive affirmative narrative to the interrogative-meditative, which is manifested in a deeper understanding of the narrator's inner man. The figurative movement of a repeating word is often due to the dynamics 
of modal semantics, the transposition of a comparative narrative into an affirmative one (for example, in sonnet IV of the "Prison Sonnets" cycle). Cultivating a sonnet as a poet, I. Franko at the same time did a lot for its study as a theorist, literary critic and interpreter (sonnets by Dante and W. Shakespeare). Ivan Franko's sonnet work is not only the culmination of the achievements of the Ukrainian sonnet at the end of the XIX century, but also a kind of foundation for further newest searches in this genre.

Key words: Ivan Franko, sonnet, poetics, word repetition, enjambment, structural and composition organization.

\section{Вступ}

Сонетний вірш Івана Франка став не лише визначною сторінкою його поетичної творчості, а й означив майбутні орієнтири розвитку сонетного жанру в українській літературі. Про новаторську природу сонета I. Франка сьогодні наявна значна дослідницька література, що досить повно розкриває пошуки поета в цій царині - тематичні, змістові, формальні. Різні аспекти мистецьких пошуків Франка-сонетяра знайшли грунтовне осмислення багатьох українських і зарубіжних авторів, зокрема на своєрідність таких пошуків звернена увага ряду сучасних літературознавців, як от: Т. Гундорова (Гундорова, 2006), Ю. Ковалів (Ковалів, 2017), Т. Охріменко (2010), Д. Павличко (Павличко, 1983), М. Ткачук (Ткачук, 2006) та ін., однак мовні особливості сонетного вірша поета не були предметом спеціального аналізу, що зумовлює потребу в подальших дослідженнях й актуальність цієї статті.

Мета цієї розвідки - простежити особливості (головно на мовному рівні) поетики сонетних творів Івана Франка. Для реалізації цієї мети важливими є такі завдання: 1) прокоментувати історико-теоретичні виміри сонетного вірша; 2) зосередитися на поглядах Франка щодо жанрових особливостей сонету; 3) дослідити й описати індивідуально-авторську специфіку поетики сонетного вірша Франка.

\section{Методи дослідження}

У статті використано описовий, функціонально-стилістичний методи, що передбачають процедури загального аналізу й систематизування досліджуваних мовних явищ, контекстуально-інтерпретаційної характеристики образних, структурно-композиційних поетичних засобів. 


\section{Виклад основного матеріалу}

В історії розвитку сонетної форми здавна культивований, закріплений традицією погляд на сонет як канонічну побудову, що має певні обмеження як на структурному, так і тематичному рівнях. Як відомо, канонічні закони сонетописання, сформульовані італійцем Антоніо да Темпо в трактаті «Summa artis rithimici vulgaris dictaminis» (1332), що пізніше, при всій суперечливості естетичної системи французького класицизиму, знайшли поетичне віддзеркалення в трактаті Нікола́ Буало-Депреó «Lart poétique» $(1674 !)^{1}$, передбачали чотирнадцятирядкову структуру з відповідною повторюваністю рим (які мали бути точними й дзвінкими); зі сталим віршовим розміром (найбільш поширеним у тій чи тій національній традиції); забороною лексичних повторів у тексті; кожна зі строф мала характеризуватися синтаксичною закінченістю тощо. Про певні обмеження стосовно сонетного вірша читаємо й у трактатах пізнішого часу. Згадаймо, Гегель відносив сонет до «ліричних жанрів у власному смислі», коли вірш «безпосередньо з внутрішньою зосередженістю виражає настрій суму, скорботи, бажання й т. ін.» та, навіть ускладнюючись багатозначним змістом, лише «обачно орієнтується в міфології, історії, в минулому і сучасному, і все ж неодмінно повертається до себе, обмежуючи й стримуючи себе» (Гегель, 1958: 313, 319-320).

I. Франка як митця, що глибоко засвоїв канон, віддавши належне йому й на практиці, не влаштовувала поширена думка про обмеженість жанру сонета лише поезією загальноліричної, інтимної, суб’єктивної стихій творчості. Зішлемося хоч би на назви сонетних творів поета: «Наука», «Котляревський», «Пісня будущини», цикл «Тюремні сонети». Як зазначав М. Ільницький, «творча практика Франка-сонетяра спростувала той погляд, згідно з яким поетичну форму можна ототожнювати зі змістом творів, що вона $є$ показником чи виразником проблематики, і що цю форму слід сприймати як щось застигле, незмінне, раз назавжди дане» (Ільницький, 2008: 578).

Усвідомлення I. Франком важливості традицій у їхньому розвитку, зважаючи на цивілізаційно-часові, індивідуалізаційно-оцінні виміри, дало змогу сформулювати діалектичний погляд на проблему поетичного творення: «...історія розвою поетичної творчості доказує нам, що така чисто індивідуальна лірика, хоч і як се нам може

${ }^{1}$ Див.український переклад М. Рильського (Буало, 1967). 
видаватись дивним, являється не на початку, а на кінці еволюції, рівночасно з тим, як і сама людська індивідуальність робиться самостійною, одержує певну ціну і почуває свою вартість супроти переможного зв’язку громади, роду, сім’ї. 3 другого боку, історія поетичних форм, будови вірша, ритму, рими та мелодії показує нам, що все се появи зовсім не відвічні, не природжені чоловікові, але витворені цивілізацією, переношені в певнім часі і серед певних обставин від народу до народу» (Франко, 1983: 248-249), чим, безперечно, зумовлені й різні видозміни, модифікаційні пошуки, зокрема й у жанрі сонета.

I. Франко, культивуючи сонетний вірш як поет, водночас немало зробив для дослідження його як теоретик, літературознавець, нарешті як перекладач (сонети Данте, Анджольєрі, Шекспіра), що й сформувало його погляди на сонет, з одного боку, як строгу змістово-строфічну побудову (прикладом може слугувати хрестоматійна поезія «Голубчики українські поети»), з другого боку, як зразок відкритості до творчих пошуків у вираженні поетичної ідеї (порівняймо в не менш відомому сонеті символіку видозмін, коли йдеться про красу “різьбленої чарки” італійсько-англійських сонетярів (Колись в сонетах Данте і Петрарка, Шекспір і Спенсер красоту співали, В форму майстерну, мов різьблена чарка, Свою любов, мов шум-вино, вливали) i “перекову” останньої на меча в “панципному” німецькому сонеті Фрідріха Рюккерта й нарешті “перекову” того самого меча На плуг обліг будущини орати, На серп, щоб жито жать, життя основу, На вили - чистить стайню Авгійову у власне Франковому вірші.

Свого часу Максим Рильський говорив, що у використанні Франком «канонічних форм треба бачити не так данину традиції, як свідоме новаторство, збагачення українського поетичного слова випробованою віками зброєю» (Рильський, 1974: 163). На власне мовному рівні в текстах Франкових сонетів можна означити ряд явищ, традиційно застережених щодо сонетного вірша, це насамперед повтори тих самих слів (іноді цілих рядків), анжамбеман - незавершеність фрази з перенесенням у наступний рядок (Із ран тих наче грім лунає в мо́ій / Душі; Гримить коритар, колоддя скрегоче / При дверях, думаєм спросоння: дзвенить / Пожарний дзвін...), уживання асоціативної, складної рими на зразок оловець - здається, мені ти - боліти, що для того часу взагалі було явищем маловживаним, тощо. 
Мав рацію І. Кошелівець у своїх розміркуваннях про сонетний вірш, говорячи, що «право на вільне поводження з усіма правилами дається тільки знанням цих правил. Ми бо легко розрізняємо, що зроблено з свідомої негації правила, а що з невігластва, а тим більше, розрізняємо якісну різницю між цими двома речами» (Кошелівець, 1954: 102). Свідома негація, як правило, зумовлена власним поглядом митця на світ, баченням його поза межі традиції, яке не нівелює, а розвиває традицію.

Насамперед помічаємо в сонетному вірші I. Франка надзвичайно вагому роль повторюваного, зокрема анафоричного, слова. Нерідко таке слово започатковує цілі синтагми в поетових творах. Неважко переконатися, що численні лексичні, синтаксичні, лексико-синтаксичні повтори в сонетах I. Франка зумовлені насамперед розумінням поета ролі таких засобів в організації смислової і динамічної структури вірша, розуміння загальної поетики творення мистецької речі. Зрештою, І. Франко, добре знайомий зі світовим сонетарієм, певне ж, не міг не зауважити й щодо тих чи тих повторів у творчості видатних майстрів жанру, які, безперечно, розумілися на таких повторах (порівняймо в знаменитому 66 сонеті Шекспіра, де єдине синтаксичне ціле трьох катренів своєрідно увиразнене анафоричним сполучником and, ужитим десять разів).

Дослідники також звернули увагу на важливість повторюваних структур у Франкових текстах іншої жанрової організації. Зокрема, М. Зеров у статті «Франко-поет» відзначав «дантівської сили терцини 3 характерним повторюванням одного виразу в початку строфи <...> і з конденсацією мислі в останньому рядку» (Зеров, 1990: 462). Про силу мистецького повтору було зауважено й у прозових творах I. Франка, наприклад, в оповіданні «Сойчине крило»: «Ритмічна організація фраз, яка найбільше виявляється у повторах однорідних синтаксичних конструкцій, в анафористичності зачинів, у німій музиці абзаців - все це набігає хвиля за хвилею й методично пробиває шкаралупу забуття, збуджує ліричний настрій, нагадує «юні дні, дні весни». Це радше мова поезії, ніж прози» (Денисюк, 2001: 40).

Анафоричне слово спрямовує розгортання віршового тексту у відповідному асоціативно-смисловому, градаційному ряді наступних рядків, строф. Анафора започатковує кожне речення синтаксичного паралелізму в обох катренах першого вірша циклу “Вольні 
сонети” (пор.: Сонети - се раби... Сонети - се пани), щоб нарешті постати в єдиній синтагмі наступної строфи (Раби й пани!), і в такій злютованості “екстрем” набути суголосної означеності в динамічній фразі заключного рядка - Живі, грізні, огромнї сонети... В іншому сонеті фраза, що започатковує перший катрен (Смішний сей свіm!), знаходить продовження в цьому ж рядку (Смішніший ще поет), але в другій і третій строфах поет знову повертає нас до анафоричного Смішний сей свіm!, щоб на узагальненому тлі (проте вже не в зіставно-порівняльному, а в сфокусованому плані) виокремити для читача досить промовистий світ ліричного персонажа, що й спостерігаємо нарешті зі всією акцентованістю, характерною для заключного терцета: Смішний поет, щзо хтів би, окрім зла, В тім світі правди й розуму глядіти.

У знаменитій «Пісні будущини» анафорична синтагма Знов час прийде (у першому й другому катренах) започатковує підрядні частини речень, у яких мовби осмислюється програма дій і боротьби на шляху до заповітної будущини. У прикінцевій строфі-замку анафоричний вислів набуває хіазмічного вираження (з винесеною наперед дієслівною домінантою-ствердженням), оформлений окремим реченням з окличною інтонацією: Прийде той час! І відповідно зміщується часова площина - ні, це ще не теперішній майбутній, але з виразною інтенцією в напрямку, окресленому анафоричною домінантою: Icmoтою изілою Ми чуєм хід його поза собою...

Поетика повторюваного слова в риторичних, риторично-запитальних реченнях стає домінантною і в ряді інших творів I. Франка. Зокрема, у сонеті VI розгляданого циклу запитальні конструкції, по суті, формують усі перші три строфи, обрамлювані короткими окличними реченнями-звертаннями до ліричної героїні, метонімічне уособлення якої в образі жіночого серця мислиться таким, яке важко наразі збагнути, про що й свідчать численні повторювані займенникові слова з запитальною часткою чи: Жіноче серие! Чи ти лід студений, Чи запашний, чудовий ивіт весни? Чи світло місяия? Огонь страшенний, Що нищить все? Чи ти, як тихі сни Невинності? Чи як той стяг воєнний, Що до побіди кличе? Чи терни, Чи рожі плодиш? Ангел ти надземний Чи демон пютий з пекла глибини? Чим б’єшся ти? Яка твоя любов? В що віриш? Чим живеш? Чого бажаєщ? В чім змінне ти, а в чім постійне? Мов! І лише в терцеті замкової частини 
займенникове ти виструнчується у ствердну синтезу анафоричного номена, що поєднує в собі діалектику любові й усі ті суперечливі стиxiï, що градаційно наростали в кожному з рядків попередніх строф:

Ти океан: маниш і потопляєш;

Ти рай, добутий за иіну оков.

Ти тіто: грієш враз і громом убиваєш.

Порівняймо також у сонеті «Сикстинська мадонна»: риторичнозапитальна конструкція першого рядка (Хто смів сказать, щзо не богиня ти?) вже в другій строфі набуває стверджувальної інтонації (Так, ти богиня!), і в подальшому образ земної богині, по суті, вивищується над цілим світом, оскільки той, що в небесах не міг знайти Богів, тепер схиляється перед рафаелівським творінням краси: лиш тебе, богине, Чтить буде вічно - тут, на полотні.

В іншому сонеті спостерігаємо зворотний образний рух - від власне констатаційної стверджувальної оповіді до запитально-медитаційної, що виявляється в глибшому осмисленні внутрішнього $Я$ ліричного героя. Відвертий категоризм, що спостерігаємо в перших трьох строфах твору (від Нi, не любив на світі я нікого до От так любить ніколи я не вмів) набуває досить відмінної модальності (медитаційного характеру) завдяки повторюваній тріаді запитальних речень наприкінці вірша:

Чи самолюбства в мні замного стало,

Чи творчих сил живих було замало?

Чи шлях життя мене фальшиво вів?

Образний рух повторюваного слова нерідко зумовлений динамікою модальної семантики, транспозицією порівняльного наративу у стверджувальний, як спостерігаємо на прикладі перших рядків початкової і заключної строф IV сонета циклу “Тюремні сонети”: Сиджу в тюрмі, мов в засідиі стрілець... Я в засідиі дрібнії точу стріли...), чи на основі порівняльної і заперечно-стверджувальної семантики, наприклад, в іншому сонеті цього ж циклу, де ринва такжалібно дирка О мур, мов хоче вирватися з пут. I далі:

Та ні, не вирвешся! Залізні гаки

Держать тебе, дозориі, як собаки,

Пильнують, ходить шельвах під вікном.

Не вирвешся! I глухне зойк розпуки,

В тяжкій знесилі опадають руки... 
Асоціативно-образне розгортання канви твору свідчить, що оте Не вирвешся! (яке ще двічі започатковуватиме терцетні строфи) вже не стільки стосується деркітливої ринви за вікном, скільки самого ліричного героя в застінках в’язничної камери.

На основі зіставлення запитально-ритоторичного і заперечностверджувального наративу відповідно в катренній і терцетній частинах другого сонета циклу «Вольні сонети» («Чого ти, хлопе, вбравсь у стрій лииарський, Немов боїшся насміху і сварки? Чого важкий свій молот каменярський Міняєи на тонкий різець Петрарки?»; «Ні, я не кинув каменярський молот, Усе він в моїй, хоч слабій, долоні...») простежуємо внутрішній діалог ліричного героя, у якому важкий каменярський молот стає мистецькою перековою ідеї в ім'я найблагородніших цілей служінню слова.

Циклічна побудова сонетних творів дає змогу авторові використовувати той чи той абстрактний номен, що отримав відповідну конкретизацію в попередньому тексті, на позначення конкретної особи навіть без будь-якого кореферентного відповідника в наступному тексті. Наприклад, висока урядова фігура цілком означено прочитується з контексту цих чотирьох рядків XXI сонета тюремного циклу: Комісія, комісія! - гуде, Мов шелест листя, як зближаєсь буря. - Висока урядовая фігура, Сам пан надрадия на контроль іде! У терцетних строфах сонета йдеться вже просто про фizуру без будь-якого означення (Стряслось - фігура в кримінал явилась), явно з іронічним підтекстом: «Замкніть вікно!»- дід крикнув нам крізь двері, Щоби фігура не перестудилась”. I вже наступний XXII сонет розпочинається описовою констатацією: Ввійшла фігура. Але читачеві тепер не потрібно жодної конкретизації щодо цієї фігури, автологічність образу підкреслюється і рядом характеристичних повторів, на зразок отого Гм у діалозі з іншими персонажами: Ввійшла фігура. "Як зветесь ви?»«Франко». «Гм, Станко?»- «Франко!»- «Станко, запишіть. Давно mут?» - «Місяиь». - «Гм...». Побачив книжку. «Маєте дозвілля Читать - «Так». - «Гм!» - На ліжка, на суфбіт Зирнув. «Гм-гм! А тут нема вентіля?» - «Нема». - «Нема? Гм, добре, запишіть!».

Своєрідним триптихом можна вважати XXIX, XXX i XXXI сонети тюремного циклу, де в першому сонеті в образах двох богинь - любові й муки-ненависті - мовби синтезовано погляд на такі суперечливі почуття, як любов і ненависть, які, проте, однаковою мірою спрямовані 
на боротьбу за добро; і в монологах до ліричного героя богиня любові (другий сонет) та богиня ненависті (третій сонет) промовляють, по суті, сестринські речі, з яких і виростає гармонія віри в людину, гармонія утвердження добра над злом (Хто з злом не боресь, той людей не любить!), що, зрештою, формулює поетичну сентенцію всього сонетного триптиха.

Гармонія любові, проголошена I. Франком у згаданому вже сонеті «Голубчики українські поети», у якому автор неупереджено виклав класичний погляд на утверджений віками канон, у творчості митця зовсім не заступає гармонії новаторських пошуків, що так промовисто постає із сонетних текстів поета.

\section{Висновки}

Сонетна творчість Івана Франка стає не лише вершинною віхою здобутків українського сонетярства наприкінці XIX-го століття, а й своєрідним підмурівком для подальших новітніх пошуків у царині сонетотворчості. Зрештою, визначне місце в цих пошуках належить самому Франкові, що знайшло відображення на рівні змістових і структурно-композиційних особливостей його поетичних текстів iз численними лексичними, синтаксичними повторами, анжамбеманними конструкціями, асоціативним і складним римуванням, що традиційно застережувалося (нерідко спостерігаємо й сьогодні) стосовно сонетного вірша.

\section{ЛІТЕРАТУРА}

1. Гегель (1958). Сочинения. Лекции по эстетике. (T. XIV. Кн. 3). Москва: Гос. соц.-эконом. изд-во. 2. Буало, Н. (1967). Мистецтвво поетичне (М. Рильський, пер.). Київ: Мистецтво. 3. Гундорова, Т. (2006). Франко не Каменяр. Франко і Каменяр. Київ: Критика. 4. Денисюк, І. (2001). Невичерпність атома. Львів: 6.в. 5. Зеров, М. (1990). Франко-поет. В Зеров, М. Твори в двох томах. (Т. 2). (с. 457-491). Київ: Дніпро. 6. Ільницький, М. (2008). Драматургія сонета. В Ільницький, М. На перехресmяx віку. (Кн. І.). (с. 576-605). Київ: Києво-Могил. акад. 7. Ковалів, Ю. (2017). Іван Франко в інтертекстуальному полі лірики. Київські полоністичні студіï, 29, 255-260. 8. Кошелівець, I. (1954). Нариси з теорії літератури. Мюнхен: Сісего. 9. Охріменко, Т. (2010). Іван Франко і його сонети. Всесвітня література та культура, 7-8, 50-51. 10. Павличко, Д. (1983). Сонети Івана Франка. В Павличко, Д. Над глибинами: Літературно-критичні статті і виступи (с. 17-27). Київ: Наук. думка. 11. Рильський, М. (1974). Іван Франко - майстер художнього слова. В Рильський, М. Слово про тітературу (с. 150-181). Київ: Дніпро. 12. Ткачук, М. (2006). Новаторство «вольних» сонетів І. Франка. Дивослово, 5, 41-45. 13. Франко, І. (1983). Козак Плахта. В Франко, І. Зібрання творів. (Т. 43). (с. 248-279). Київ: Наук. думка. 


\section{REFERENCES}

1. Gegel'. (1958). Sochineniya. Lekcii po estetike [Compositions. Lectures on aesthetics]. (Vol. XIV. Part. 3). Moskva: Gos. soc.-e'komom. izd-vo [in Russian]. 2. Bualo, N. (1967). Mystetstvo poetychne [Poetic art] (M. Rylskyi, trans.). Kyiv: Mystetstvo [in Ukrainian]. 3. Hundorova, T. (2006). Franko ne Kameniar. Franko i Kameniar. Kyiv: Krytyka [in Ukrainian]. 4. Denysiuk, I. (2001). Nevycherpnist atoma [Inexhaustibility of the atom]. Lviv: b.v. [in Ukrainian]. 5. Zerov, M. (1990). Franko-poet [Franko-poet]. In Zerov, M. Tvory $v$ dvokh tomakh - Works in two volumes. (Vol. 2). (pp. 457-491). Kyiv: Dnipro [in Ukrainian]. 6. Ilnytskyi, M. (2008) Dramaturhiia soneta [The drama of the sonnet]. In Ilnytskyi, M. Na perekhrestiakh viku - At the crossroads of age. (Part I). (pp. 576-605). Kyiv: Kyievo-Mohylianska akademiia [in Ukrainian]. 7. Kovaliv, Yu. (2017). Ivan Franko $\mathrm{v}$ intertekstualnomu poli liryky [Ivan Franko in the intertextual field of lyrics]. Kyivski polonistychni studii - Kyiv Polonistic Studies, 29, 255-260 [in Ukrainian]. 8. Koshelivets, I. (1954). Narysy z teorii literatury [Essays on the theory of literature]. Miunkhen: Cicero [in Ukrainian]. 9. Okhrimenko, T. (2010). Ivan Franko i yoho sonety [Ivan Franko and his sonnets]. Vsesvitnia literatura ta kultura - World literature and culture, 7-8, 50-51 [in Ukrainian]. 10. Pavlychko, D. (1983). Sonety Ivana Franka [Sonnets by Ivan Franko]. In Pavlychko, D. Nad hlybynamy: Literaturno-krytychni statti $i$ vystupy - Above the depths: Literary-critical articles and speeches (pp. 17-27). Kyiv: Nauk. dumka [in Ukrainian]. 11. Rylskyi, M. (1974). Ivan Franko - maister khudozhnoho slova [Ivan Franko is a master of the artistic word]. In Rylskyi, M. Slovo pro literaturu - A word about literature (pp. 150181). Kyiv: Dnipro [in Ukrainian]. 12. Tkachuk, M. (2006). Novatorstvo «volnykh» sonetiv I. Franka [Innovation of «free» sonnets by Ivan Franko]. Dyvoslovo, 5, 41-45 [in Ukrainian]. 13. Franko, I. (1983). Kozak Plakhta [Cossack Plakhta]. In Franko, I. Zibrannia tvoriv Collected works. (Vol. 43). (pp. 248-279). Kyiv: Nauk. dumka [in Ukrainian].

Мойсієнко Анатолій Кирилович - доктор філологічних наук, професор, завідувач кафедри української мови та прикладної лінгвістики, Київський національний університет імені Тараса Шевченка; бульвар Тараса Шевченка, 14, Київ, 01601, Україна.

Tel. +38 097-566-07-89

E-mail: anmoj@ukr.net

http://orcid.org/ 0000-0002-7856-2746

Moisiienko Anatolii Kyrylovych - Doctor of Philological Sciences, Professor, Head of the Department of Ukrainian Language and Applied Linguistics, Taras Shevchenko Kyiv National University; 14 Taras Shevchenko Boulevard, Kyiv, 01601, Ukraine.

Надійшла до редакції 16 березня 2021 року

\section{CITATION}

ДСТУ 8302:2015: Мойсієнко А. К. Про деякі особливості сонетного вірша Івана Франка. Лінгвістичні дослідження: зб. наук. пр. Харк. нац. пед. ун-ту імені Г. С. Сковороди. Харків, 2021. Вип. 54. Ч. I. C. 145-154. DOI: https://doi.org/10.34142/23127546. 2021.54.1.12

AРА: Мойсієнко, А. К. (2021). Про деякі особливості сонетного вірша Івана Франка. Лінгвістичні дослідження, 54 (I), 145-154. DOI: https://doi.org/10.34142/ 23127546.2021.54.1.12 